\title{
Permissiveness of bovine epithelial cells from lung, intestine, placenta and udder for infection with Coxiella burnetii
}

\author{
Katharina Sobotta ${ }^{1}$, Katharina Bonkowski ${ }^{1}$, Elisabeth Liebler-Tenorio ${ }^{1}$, Pierre Germon ${ }^{2}$, Pascal Rainard ${ }^{2}$, \\ Nina Hambruch ${ }^{3}$, Christiane Pfarrer ${ }^{3}$, Ilse D. Jacobsen ${ }^{4}$ and Christian Menge ${ }^{1 *}$
}

\begin{abstract}
Ruminants are the main source of human infections with the obligate intracellular bacterium Coxiella (C.) burnetii. Infected animals shed high numbers of C. burnetii by milk, feces, and birth products. In goats, shedding by the latter route coincides with C. burnetii replication in epithelial (trophoblast) cells of the placenta, which led us to hypothesize that epithelial cells are generally implicated in replication and shedding of C. burnetii. We therefore aimed at analyzing the interactions of C. burnetii with epithelial cells of the bovine host (1) at the entry site (lung epithelium) which govern host immune responses and (2) in epithelial cells of gut, udder and placenta decisive for the quantity of pathogen excretion. Epithelial cell lines [PS (udder), FKD-R 971 (small intestine), BCEC (maternal placenta), F3 (fetal placenta), BEL-26 (lung)] were inoculated with C. burnetii strains Nine Mile I (NMI) and NMII at different cultivation conditions. The cell lines exhibited different permissiveness for $C$. burnetii. While maintaining cell viability, udder cells allowed the highest replication rates with formation of large cell-filling Coxiella containing vacuoles. Intestinal cells showed an enhanced susceptibility to invasion but supported C. burnetii replication only at intermediate levels. Lung and placental cells also internalized the bacteria but in strikingly smaller numbers. In any of the epithelial cells, both Coxiella strains failed to trigger a substantial IL-1 $\beta$, IL-6 and TNF-a response. Epithelial cells, with mammary epithelial cells in particular, may therefore serve as a niche for $C$. burnetii replication in vivo without alerting the host's immune response.
\end{abstract}

\section{Introduction}

Coxiella $(C$.) burnetii is a Gram-negative, obligate intracellular pathogen and causative agent of $\mathrm{Q}$ fever, a widely distributed zooanthroponosis [1]. The disease appears as an acute, flu-like and self-limiting illness, or manifests as a chronically progressing infection (e.g., endocarditis, premature delivery in pregnant women). C. burnetii has a broad host spectrum, which includes birds, reptiles, arthropods and domestic and wild mammals. Sources of human infections often are infected sheep, goats or cattle [2]. In livestock, C. burnetii infection is inapparent in most cases [1]. If disease manifests, referred to as

\footnotetext{
${ }^{*}$ Correspondence: christian.menge@fli.de

1 Institute of Molecular Pathogenesis, Friedrich-Loeffler-Institut (FLI),

Naumburger Strasse 96a, 07743 Jena, Germany

Full list of author information is available at the end of the article
}

Coxiellosis, reproductive disorders such as abortions, stillbirth in goats and sheep or delivery of weak newborns in cattle were observed [3]. The main route of C. burnetii transmission is via inhalation of infected aerosols or dust, especially when contaminated with C. burnetii birth products (placental membranes and fluids) of goat and sheep, but also by feces and milk $[4,5]$. An unprecedented large Q-fever outbreak occurred from 2007 to 2011 in the Netherlands, where more than 4000 human cases were notified and approximately 52000 ruminants were culled as part of the countermeasures taken to control the epidemic [6].

Main shedding of $C$. burnetii with about $10^{9}$ bacteria per gram placenta is observed during parturition in sheep and goat [1]. Coxiella organisms are primarily detected in trophoblast cells in the placentomes [2, 7, 8]. Shedding of bacteria by milk of asymptomatic cattle was observed 
to persist for several months [9]. Dairy cows seem to be more chronically infected with $C$. burnetii than small ruminants. Guatteo et al. [10] could also show that Coxiella shedding was scarce and sporadic in feces of cattle, whereas permanent and sporadic shedding was observed by milk. PCR analysis of bovine bulk tank milk samples detected more than $10^{2}$ C. burnetii DNA equivalents per milliliter [11]. Muskens et al. [12] believe that the localization of the pathogen in the bovine udder is the critical factor for a secretion of bacteria into the milk but it is currently unknown which cell types facilitate persistence and replication of $C$. burnetii in the mammary gland.

The chain of events implicated in C. burnetii transmission between animals of the reservoir species have poorly been studied at the cellular level. Mononuclear phagocytes, e.g., macrophages and monocytes, are considered the major host cells during natural infection [1]. We recently showed that Coxiella organisms invade primary bovine monocyte-derived and alveolar macrophages in vitro and slowly replicate in these cells without significantly activating them [13]. Even though alveolar macrophages probably represent the first target cell for C. burnetii when entering the body, it is highly likely that alveolar epithelial cells also become exposed to and infected by these bacteria in the early stages of the infection as described in rodent models $[14,15]$. At the site of entry, the lung epithelium therefore may determine the character of the subsequent immune response in concert with alveolar macrophages. It is also perceivable that epithelial cells at the exit sites are determinative for persistence in and bacterial transmission of C. burnetii from the reservoir host $[1,4]$.

In general, $C$. burnetii is able to grow in a number of cell types, like Vero cells or fibroblast cells [1]. All these cell types poorly mirror the natural cell environment to investigate infection processes in domestic animals. Therefore the present study aimed at developing an in vitro cell system deploying bovine epithelial cell lines from lung, placenta, gut and udder tissues. We studied the permissiveness and host cell response of different epithelial cells with two Coxiella strains: a virulent strain (Nine Mile I), expressing full-length lipopolysaccharide ("smooth LPS"), and an avirulent strain (NM phase II). NMII lacks the full O-polysaccharide I chain and sugars located in the LPS I outer core (called "rough LPS") [16].

\section{Materials and methods \\ Epithelial cell culture}

Source, origin and characteristics of bovine epithelial cells used in this study are provided in Table 1. The epithelial origin of all cell lines deployed was confirmed by detection of cytokeratin and zonula occludens protein (ZO-2) via fluorescence microscopy and western blot analysis (data not shown). Cell culture media were obtained from Life Technologies (Darmstadt, Germany). The basis culture medium of the bovine udder epithelial cells (PS) was supplemented with Insulin-like growth factor 1 (10 ng/mL; Peprotech, Hamburg, Germany), Fibroblast growth factor (5 ng/mL Peprotech), Epidermal growth factor (5 ng/mL; Sigma, Taufkirchen, Germany), Hydrocortisone $(1 \mu \mathrm{g} / \mathrm{mL}$; Sigma), $20 \mathrm{mM}$ HEPES buffer (Fisher Scientific, Schwerte, Germany) and $2 \mathrm{mM}$ L-Glutamine (Life Technologies) [17]. Maintenance media were supplemented with $10 \%$ fetal bovine serum [FBS, Fisher Scientific; heat-inactivated $\left(56{ }^{\circ} \mathrm{C}\right.$ for $\left.30 \mathrm{~min}\right)$ ]. Test media used in experiments for invasion analysis, cell vitality test and cytokine analysis contained 1\% FBS. Epithelial cells were grown and maintained in an atmosphere of $5 \% \mathrm{CO}_{2}$ at $37^{\circ} \mathrm{C}$. Detachment of the cells was done with Trypsin/EDTA solution $[\mathrm{NaCl} 0.8 \%(w / v), \mathrm{KCl}$

Table 1 Cell lines used in this study

\begin{tabular}{|c|c|c|c|c|c|c|}
\hline \multirow[t]{2}{*}{ Code } & \multirow[t]{2}{*}{ Clone } & \multicolumn{2}{|l|}{ Origin } & \multirow[t]{2}{*}{ Culture medium } & \multirow[t]{2}{*}{ Source } & \multirow[t]{2}{*}{ Reference } \\
\hline & & Organ & Donor & & & \\
\hline$L$ & BEL-26 & Lung & Fetal & Dulbecco's Modified Eagle Medium (DMEM, $1.0 \mathrm{~g} / \mathrm{mL}$ glucose) & CCLV $^{a}$ & $(-)$ \\
\hline G & $\begin{array}{c}\text { FKD-R } \\
971\end{array}$ & Jejunum & Fetal & $\begin{array}{l}\text { Iscove's Modified Dulbecco's Medium (IMDM)/Ham's F12 nutrient mix } \\
{[1: 1]}\end{array}$ & CCLV $^{a}$ & $(-)$ \\
\hline Pm & BCEC & $\begin{array}{l}\text { Maternal pla- } \\
\text { centa }\end{array}$ & Mature/pregnant & DMEM (4.5 g/mL glucose)/Ham's F12 nutrient mix [1:1] & $\mathrm{TiHo}^{\mathrm{b}}$ & {$[35]$} \\
\hline Pf & F3 & Fetal placenta & Mature/pregnant & DMEM (4.5 g/mL glucose)/Ham's F12 nutrient mix [1:1] & $\mathrm{TiHo}^{\mathrm{b}}$ & {$[36]$} \\
\hline$U$ & PS & Udder & Mature & $\begin{array}{l}\text { Advanced DMEM/Ham's F12 nutrient mix [1:1] + additional } \\
\text { components }^{d}\end{array}$ & INRA $^{c}$ & {$[17]$} \\
\hline
\end{tabular}

\footnotetext{
a Collection of Cell Lines in Veterinary Medicine (CCLV) at Friedrich-Loeffler-Institut (Isle of Riems), Germany; cell line FKD-R 971 was generated by Roland Riebe (RIE 971).

b Christiane Pfarrer, Department of Anatomy, University of Veterinary Medicine, Hannover, Germany.

c Pascal Rainard, ISP, INRA, Université Tours, Nouzilly, France.

d See "Materials and methods".
} 
$0.08 \%$ (v/v), Dextrose 0.1\% (w/v), $\mathrm{Na}_{2} \mathrm{HCO}_{3} 0.058 \%(\mathrm{w} / \mathrm{v})$, Trypsin $0.05 \%(\mathrm{w} / \mathrm{v})$, EDTA $0.02 \%(\mathrm{w} / \mathrm{v})]$ for $5 \mathrm{~min}$ at $5 \%$ $\mathrm{CO}_{2}$ at $37{ }^{\circ} \mathrm{C}$. Cells were seeded into 96-, 24- or 6-well plates with $1 \times 10^{4}, 4-10 \times 10^{4}$ and $2-3 \times 10^{5}$ cells, respectively, and cultured for $2-3$ days to reach a confluent cell monolayer.

\section{Coxiella (C.) burnetii infection and sampling}

Cells were infected with $C$. burnetii strain "Nine Mile phase I RSA 493" (NMI) and "Nine Mile phase II clone 4" (NMII) (phase I-LPS and phase II-LPS expressing variants, respectively) in multi-well cell culture plates at $37^{\circ} \mathrm{C}$ and $5 \% \mathrm{CO}_{2}$. Both C. burnetii strains were supplied, propagated and purified as previously described [13].

Once cells had formed a monolayer, cell numbers from a reference well were determined by detaching with Trypsin/EDTA solution and subsequent microscopic cell counting with a Neubauer chamber. Cells were infected with a multiplicity of infection (MOI) of 100 or mock infected with $\mathrm{NaCl}$ solution. C. burnetii inocula were left in the cultures for 7 days (infection strategy A; Figure 1). Alternatively, non-internalized bacteria were removed $24 \mathrm{~h}$ after inoculation by washing two to three times with pre-warmed $\left(37^{\circ} \mathrm{C}\right) 1 \times \mathrm{PBS}$ and fresh culture test medium (1\% FBS) was added (infection strategy B). During each set of experiments, supernatants (extracellular fraction) and cells (cell-associated fraction) were sampled directly after inoculation at time point " $0 \mathrm{~h}$ " ("regained inoculum"; experimental settings $\mathrm{A}_{1}, \mathrm{~B}_{1}$ ), after 24 h (" 1 day"; experimental settings $A_{2}, B_{2}$ ) or after 7 days ("7 days"; (experimental settings $A_{3}$ and $B_{3}$ ) from separate wells. To this end, wells were washed two to three times with warm $1 \times$ PBS and cells were detached by incubation with Trypsin/EDTA solution. To inactivate C. burnetii, samples were treated with three freeze $\left(-80{ }^{\circ} \mathrm{C}\right) /$ thaw cycles and subsequently incubated for $30 \mathrm{~min}$ at $95^{\circ} \mathrm{C}$. For detection of host cell immune response, cells were inoculated following infection strategy $B_{2}$ or $B_{3}$, or stimulated with LPS of E. coli O111:B4 $(5 \mu \mathrm{g} / \mathrm{mL})$ as a control. Cells were harvested for RNA isolation 1 and 7 days post-infection (pi). Total RNA was extracted with RNeasy Mini Kit (Qiagen, Hilden, Germany) according to the instructions of the manufacturer. To avoid DNA contamination RNA was purified with the RNase-free DNase set (Qiagen). For immunofluorescence microscopy studies, infected cells were inoculated following strategy $B_{3}$.

\section{Immunofluorescence microscopy}

Cells were cultured in 24-well plates $\left(\right.$ Corning $^{\circledR}$ Costar $^{\circledR}$, Sigma) until at least $80 \%$ confluence was reached and infected with NMI and NMII with a MOI of 100 as described above. Cell vitality was monitored by MTT and LDH assay (according to manufacturer's instructions). After 7 days of infection (see above), cells were fixed

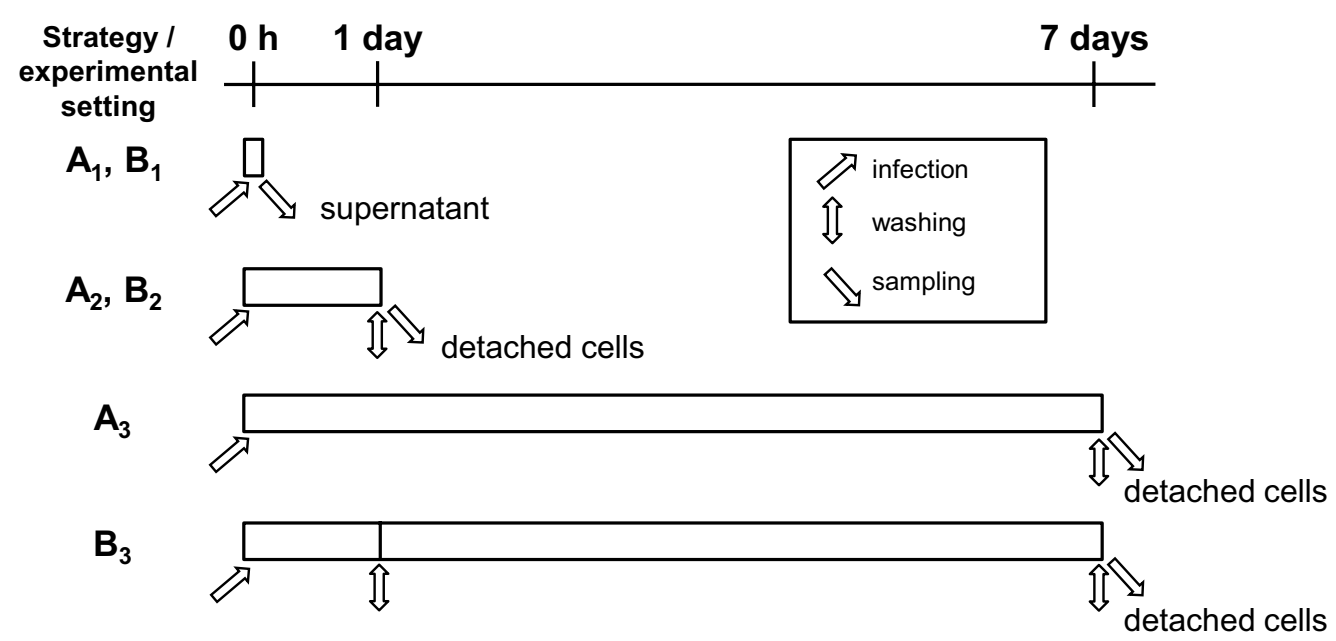

Figure 1 Study design. Invasion and replication of C. burnetii in bovine epithelial cell lines were quantified applying two different infection strategies differing in the time the inocula were left with the cells. Strategy B included a washing step after 1 day; in strategy A, inocula were not removed for the duration of the experiment. "Invasion B" refers to the quantitation of cell-associated C. burnetii genome equivalents (GE) $24 \mathrm{~h}$ after inoculation (values obtained in experimental setting $B_{2}$ ), "invasion A" to the quantitation of cell-associated GE after 7 days (values obtained in experimental setting $A_{3}$ ), each normalized to the GE numbers detected in the supernatant regained immediately after inoculation (time point " $0 \mathrm{~h}^{\text {"; }}$ values obtained in experimental settings $A_{1}$ and $\left.B_{1}\right)$. Thus the invasion was calculated as follows: $(A) \times=\left(A_{3} \times 100 \%\right) / A_{1}$ and $(B) \times=\left(B_{2} \times 100 \%\right) / B_{1}$. Replication efficiency was calculated as the fold-increase in the number of cell-associated GE from day 1 (values obtained in experimental setting $A_{2}$ and $B_{2}$ ) to values at day 7 (obtained in experimental setting $A_{3}$ and $B_{3}$ ). Thus the replication efficiency was calculated as follows: $(A)=A_{3} / A_{2}$ and $(B)=B_{3} / B_{2}$. Arrow depict sampling event, i.e. taking off the supernatant, washing the cell monolayer and detachment of the cells. 
with $4 \%$ formaldehyde for $24 \mathrm{~h}$ and stored at $4{ }^{\circ} \mathrm{C}$. Cells were washed with $1 \times$ PBS and permeabilized with $100 \%$ ice cold methanol for $1 \mathrm{~min}$ followed by incubation with $50 \mathrm{nM} \mathrm{NH}_{4} \mathrm{Cl}$ for $15 \mathrm{~min}$ and PBS/FBS solution (1\% FBS) for 30-45 min in the dark at room temperature to block unspecific binding sites. Cells were stained for $30 \mathrm{~min}$ at room temperature using an Anti-Coxiella antibody [1:5000 in PBS/FCS] (kindly provided by Anja Lührmann, Friedrich-Alexander-Universität Erlangen-Nürnberg, Germany) followed by incubation ( $30 \mathrm{~min}-1 \mathrm{~h}$ ) with a fluorochrome-conjugated secondary antibody [1:500 in PBS/ FCS] [Anti-rabbit IgG $(\mathrm{H}+\mathrm{L}), \mathrm{F}(\mathrm{ab}) 2$ Fragment (Alexa Fluor $^{\circledR}$ 594 Conjugate), New England Biolabs, Frankfurt, Germany], counterstained with 4',6-diamidino-2-phenylindole (DAPI) for $5 \mathrm{~min}$ at room temperature followed by washing with $1 \times$ PBS. To characterize the replication compartment of $C$. burnetii, infected cells were labeled with the acidic marker LysoTracker Red DND-99 (Invitrogen, Darmstadt, Germany). After infection, cells were incubated with LysoTracker (1:5000 in test media) for $2 \mathrm{~h}$ at $37{ }^{\circ} \mathrm{C}$ following fixation as described above. The cells were mounted in DABCO (1,4-diazabicyclo[2.2.2]octane, $2 \%$ in Glycerol). Samples were viewed under a fluorescence microscope [Olympus CK40; camera: Leica DFC420C, software: Leica Application Suite (LAS) Version 3.7.0 (Build: 681)]. Cultures incubated in PBS without primary antibodies served as negative controls.

\section{Transmission electron microscopy (TEM)}

Cells were cultured in 6-well plates $\left(\right.$ Corning $^{\circledR}$ Costar $^{\circledR}$, Sigma) and infected with infection strategy $B_{3}$ as described above. The culture supernatant was removed and cells were fixed with $2.5 \%$ glutaraldehyde in cacodylate buffer $(0.1 \mathrm{M}, \mathrm{pH} 7.2)$ for $2 \mathrm{~h}$ at $4{ }^{\circ} \mathrm{C}$, detached with a cell scraper from the culture plate, collected in a reaction tube and centrifuged to obtain a cell pellet [18]. The cell pellet was embedded in $2 \%$ agarose and sectioned to $1 \mathrm{~mm}^{3}$ cubes. Cubes were post fixed in $2 \%$ osmium tetroxide and embedded in araldite Cy212. Ultrathin sections $(85 \mathrm{~nm})$ were stained with uranyl acetate and lead citrate. They were examined at an accelerating voltage of $80 \mathrm{kV}$ by transmission electron microscopy (Tecnai12, FEI, Eindhoven, Netherlands).

\section{Quantitative real-time PCR for determination of intracellular C. burnetii genome equivalents (GE)}

To estimate the number of cell associated bacteria, DNA from the cell containing fraction of the cultures of infection strategy A and B was purified with the Invisorb ${ }^{\circledR}$ DNA Cleanup-Kit (Stratec, Birkenfeld, Germany) according to manufacturer's instructions. The number of genome equivalents (GE) was monitored by quantitation of the isocitrate dehydrogenase $(i c d)$ gene by quantitative real-time PCR (qPCR) [19]. The icd gene is highly conserved within the species $C$. burnetii and occurs as single copy in the Coxiella genome. Ct values of technical duplicates varied by less than 0.51 and were used to calculate GE considering values obtained with an entrained $i c d$ harbouring plasmid standard. Invasion rate and replication efficiency were calculated from four biological replicates (independent cell cultures, tested in two technical replicates each) as described in the legend to Figure 1.

\section{Flow cytometry analysis}

Cells $\left(4 \times 10^{5}\right.$ cells/well, 24 well plates $)$ were detached by Trypsin/EDTA solution and transferred to microtiter plates (V-shape; Greiner Bio-One GmbH, Frickenhausen, Germany) and pelletized by centrifugation $(400 \times g$, $4 \mathrm{~min}$ and $4{ }^{\circ} \mathrm{C}$ ). For detection of CR3 [CD11b, MM12A, diluted 1:250 (VMRD, Pullman, WA, USA)] and $\alpha_{\mathrm{v}} \beta_{3}$ [CD61, diluted 1:100 (AbD Serotec, Düsseldorf, Germany)], cells were incubated with $50 \mu \mathrm{L}$ diluted primary antibody for $20 \mathrm{~min}$. After washing (washing buffer: $1 \times$ PBS, 0.5\% FCS), cells were incubated with secondary antibody antimouse IgG1-APC (Southern Biotech, Birmingham, USA) diluted 1:1000 in $1 \times$ PBS for 20 min. Finally cells were washed again and analyzed with BD FACSCanto ${ }^{\mathrm{TM}} \mathrm{II}$ (Becton-Dickinson, Heidelberg, Germany). Data was analyzed with BD FACSDIVA ${ }^{\mathrm{TM}}$ software (version 6).

Reverse transcription and cytokine-specific real time PCR Equal amounts of RNA from each sample were reversely transcribed into cDNA as described previously [13]. Levels of relative gene expression of different cytokines in comparison to GAPDH as housekeeping gene were determined by quantitative real-time SYBR Green-based (Applied Biosystems, Waltham, USA) PCR (qPCR) using ABI Prism ${ }^{\circledR} 7500$ (Applied Biosystems). All primers (Table 2) were run at an annealing temperature of $60^{\circ} \mathrm{C}$. The reaction profile applied was: denaturation $(10 \mathrm{~min}$, $\left.95{ }^{\circ} \mathrm{C}\right)$, annealing $\left(1 \mathrm{~min}, 60^{\circ} \mathrm{C}\right.$; 39 cycles) and melting step $\left(15,60^{\circ} \mathrm{C}\right)$. Ct values for GAPDH-specific mRNA were not subject to variation along the incubation period and values from infected cells did not differ from noninfected control cells (data not shown). Relative gene

Table 2 Sequences of primers used in this study

\begin{tabular}{|c|c|}
\hline Primer & Sequence $5^{\prime}-3^{\prime}$ \\
\hline GAPDH & $\begin{array}{l}\text { F: GCG ATA CTC ACT CTT CTA CCT TCG A } \\
\text { R:TCG TAC CAG GAA ATG AGC TTG AC }\end{array}$ \\
\hline $\mathbb{I L}-1 \beta$ & $\begin{array}{l}\text { F: ACC TGA ACC CAT CAA CGA AAT G } \\
\text { R:TAG GGT CAT CAG CCT CAA ATA ACA }\end{array}$ \\
\hline IL-6 & $\begin{array}{l}\text { F: CTG AAG CAA AAG ATC GCA GAT CTA } \\
\text { R: CTC GTT TGA AGA CTG CAT CTT CTC }\end{array}$ \\
\hline TNF-a & $\begin{array}{l}\text { F: TCT TCT CAA GCC TCA AGT AAC AAG T } \\
\text { R: CCA TGA GGG CAT TGG CAT AC }\end{array}$ \\
\hline
\end{tabular}


expression levels were calculated by using relative expression software REST [20].

\section{Statistical analysis}

Unless otherwise indicated, Mann-Whitney U test was used to compare two different samples. A $p$ value of $\leq 0.05$ ("a" or "*") show a statistically significant difference at the $95 \%$ confidence level, a $p$ value of $\leq 0.01$ (" $\mathrm{b}$ " or “*:*") at the $99 \%$ confidence level.

\section{Results}

\section{Bovine udder epithelial cells exhibited highest} permissiveness for $C$. burnetii propagation

Bovine epithelial cells from different tissues varied in their susceptibility to C. burnetii invasion and support of replication (Figure 2). In the experimental setting in which the inocula were left with the cells for 7 days (strategy A), higher numbers of genome equivalents (GE) of C. burnetii NMI and NMII were found cell-associated relative to the number in the regained inoculum (upper left graphs in Figures 2A and B; "invasion A") only in the udder (U) epithelial cell line. The intestinal epithelial cell line $(G)$ allowed moderate invasion of both NM strains. Regardless of the strain, very few bacteria were detected inside lung (L) and placental cells with fetal placental cells (Pf) containing more bacteria than maternal placental cells (Pm) which exhibited the lowest permissiveness for $C$. burnetii propagation throughout. Invasion rates in epithelial cell lines were not significantly different for NMI and NMII.

NMI and NMII, both showed a very low invasiveness within the first $24 \mathrm{~h}$ after inoculation (lower left graphs in Figures 2A and B; "invasion B") under the experimental conditions applied. The udder epithelial cell line was only slightly more susceptible to incorporate C. burnetii than the lung and placental cell lines but differences did not reach statistical significance. Interestingly, although numbers markedly varied between biological replicates, intestinal epithelial cells exhibited the highest susceptibility for C. burnetii invasion within the first $24 \mathrm{~h}$ after inoculation.

Increases in C. burnetii-specific GE numbers during 7 days of culture following strategy A (upper right graphs in Figures 2A and B), reflect efficacy of C. burnetii replication but may also be influenced by invasion events having occurred later than $24 \mathrm{~h}$. In order to dissect these two phenomena, excess, i.e., not yet cell-bound C. burnetii particles were removed $24 \mathrm{~h}$ after inoculation ("strategy B"; lower right graphs in Figures 2A and B). GE numbers were then quantified at day 7 and calculated relative to the numbers found cell-associated after $24 \mathrm{~h}$ of culture. It became apparent that udder epithelial cells were most effective in supporting replication of NMI and
NMII ("replication B"): while numbers of NMI increased by approx. 16000 -fold from day 1 to day 7 , numbers of NMII increased by approx. 330-fold ( $p=0.032$ ). Replication efficiency of NMI and NMII in intestinal epithelial cells was not significantly different from lung and maternal placental cells but fetal placental cells exhibited an intermediate support of $C$. burnetii replication.

\section{Large Coxiella containing vacuoles (CCV) were formed in gut and udder epithelial cells without affecting viability of the cell cultures}

Immunofluorescence microscopy was applied to investigate the number and distribution of Coxiella organisms within epithelial cells 7 days after inoculation of monolayers (Figure 3). In corroboration of icd qPCR results, single cells, uniformly distributed within the monolayers of lung and placental epithelial cells harbored C. burnetii and bacterial accumulations were very small. Inoculation of cultures with NMI and NMII yielded comparable results. Monolayers of gut cells showed more infected cells but Coxiella clusters within cells also were small. The highest amount of bacterial accumulations was observed in udder cells, they were more closely spaced and filled up the whole cell. As reported for other C. burnetii-susceptible cell types, CCVs in udder epithelial cells induced by either of the C. burnetii strains presented as acidic compartments (Figure 4). In addition, small acidified vesicles were observed inside the infected cells next to the CCV (data not shown). A strong fluorescent signal of the LysoTracker Red dye inside the formed vacuoles indicated that phagosomal-lysosomal fusion had occurred.

By transmission electron microscopy numerous $\mathrm{CCV}$ were detected in udder and very few in intestinal cells at day 7 pi (Figures 5 and 6). Findings were comparable after infection with strains NMI and NMII. CCV were filled at a variable degree with large cell variants (LCV) representing the metabolically active form and small cell variants (SCV) representing the dormant form of C. burnetii. LCV had diameters of up to $400 \mathrm{~nm}$ and finely granular cytoplasma; SCV were about $150 \mathrm{~nm}$ in diameter, more electron dense and often had a highly electron dense central core. LCV and SCV were surrounded by a Gramnegative cell envelope formed by an inner membrane, a delicate cell wall, a periplasmic space and an outer membrane. The presence of both SCV as well as LCV indicates that $C$. burnetii undergoes a complete life cycle in udder and intestinal cells. CCV in udder cells were large and displaced most of the cytoplasm (Figure 5). Very large CCV which were often ruptured and contained few C. burnetii predominated. Since the cellular cytoplasm surrounding these CCV was very thin, their rupture may be artificial due to mechanical forces during processing. 

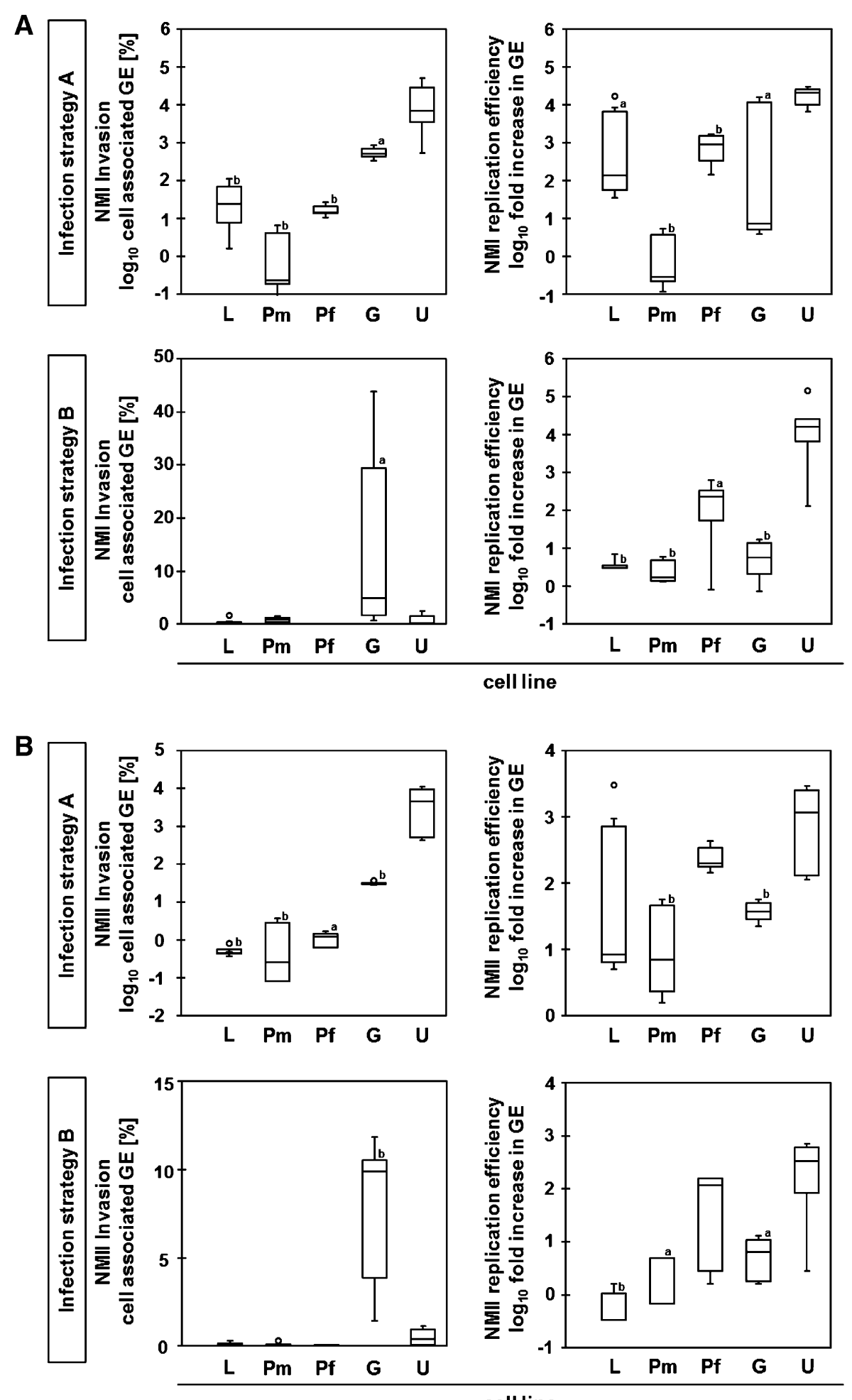

Figure 2 Invasion and replication efficiency of $\mathbf{C}$. burnetii in different bovine epithelial cell lines. Efficiencies were determined following the study design described in Figure 1. The relative numbers of cell-associated genome equivalents of C. burnetii (GE) of NMI (A) and of NMII (B) were determined by icd qPCR. Significant differences between udder cells and other epithelial cell lines were determined by Mann-Whitney $\mathrm{U}$ test (a: $p \leq 0.05 ; \mathrm{b}: p \leq 0.01$ ); L-Bel-26 (lung), Pm—BCEC (maternal placenta), Pf—F3 (fetal placenta), G—FKD-R 971 (jejunum), U—PS (udder). 


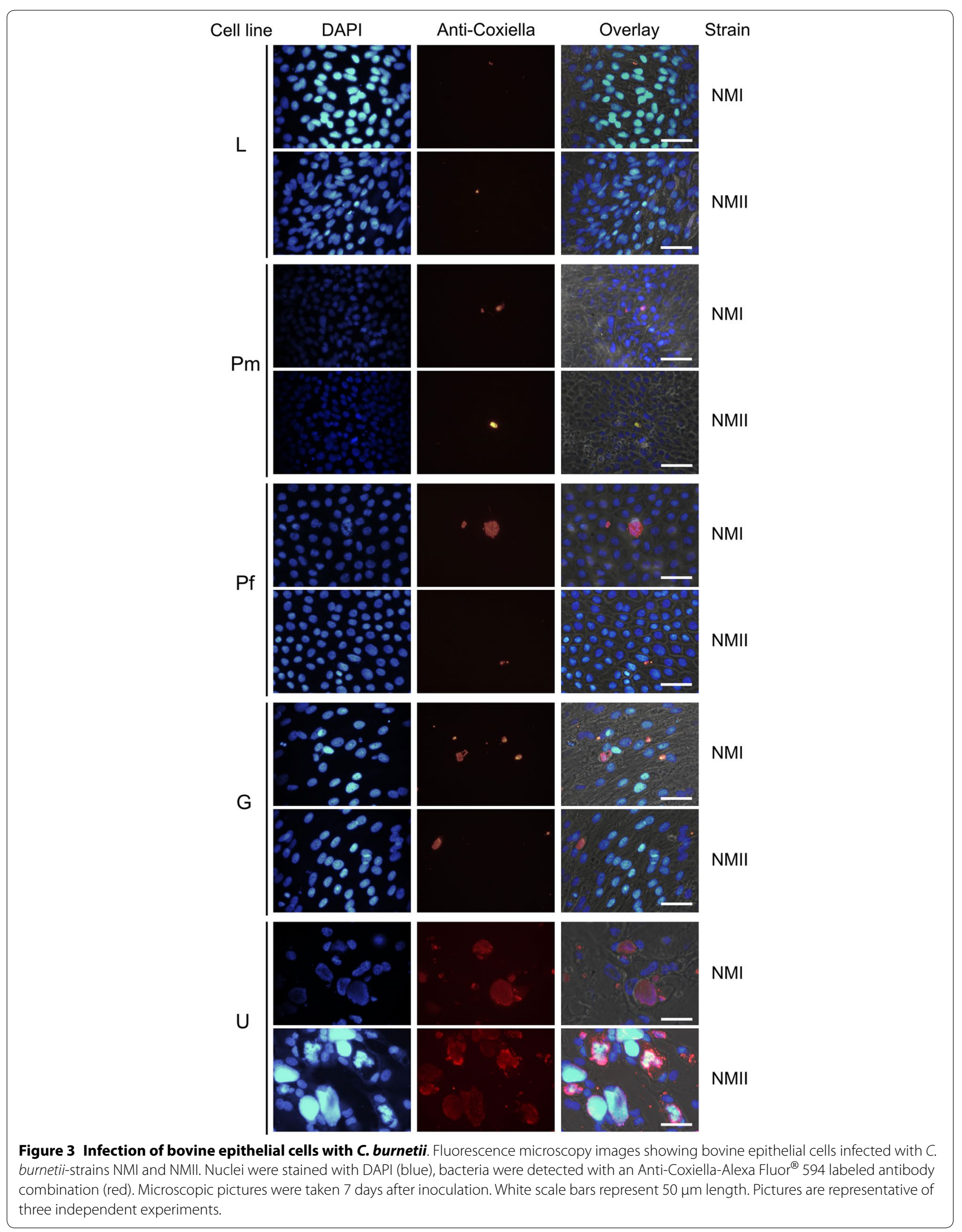


$\mathrm{LCV}$ and SCV in the extracellular space originated from the described CCV. Some CCV were densely packed with C. burnetii. Most of them were mainly filled with LCV, but in a few CCV both LCV and SCV were present. Small amounts of cellular debris were regularly admixed with $C$. burnetii. Intestinal epithelial cells were characterized by numerous, sometimes large phagolysosomes. Small numbers of LCV and SCV were present in very few of these phagolysosomes only (Figure 6). They were obscured by the large amounts of cellular debris. No extracellular $C$. burnetii were detected.

Epithelial cells infected with NMI or NMII retained their typical cell morphology after 7 days of infection and displayed no signs of cell death processes, e.g., disrupted cell membrane or fragmented nuclei. These observations could be confirmed by cell vitality assays. Independent of the C. burnetii strain, infection neither affected metabolic activity nor cytoplasmic membrane integrity of any of the epithelial cell lines after 1 and 7 days of inoculation compared to uninfected control cells (data not shown).

\section{CR3 and $\alpha_{v} \beta_{3}$ surface expression does not correlate} with epithelial susceptibility to $C$. burnetii invasion Uptake of NMI is mediated by leukocyte response integrin (LRI $\alpha_{\mathrm{v}} \beta_{3}$ ) whereas the avirulent C. burnetii enters host cells through the combination of $\alpha_{v} \beta_{3}$ and CR3 (complement receptor 3) [21]. To investigate whether differences in the susceptibility of bovine epithelial cells to $C$. burnetii invasion can be explained by varying cell surface expression pattern of these antigens, we applied flow cytometry analysis on fetal placental, intestinal and udder epithelial cells (Figure 7). All cells of the cell lines studied expressed $\alpha_{v} \beta_{3}$. While fetal placental and intestinal epithelial cells expressed the integrin in comparable densities (as deduced from the distribution of fluorescence signals for the detection of the antigens), udder epithelial cells exhibited an enhanced $\alpha_{\mathrm{v}} \beta_{3}$ expression. Expression of CR3 was barely detectable on all cell lines. Expression pattern of these molecules therefore neither correlate with the enhanced susceptibility of intestinal epithelial cells for C. burnetii invasion nor with the fact that udder epithelial cells particularly supported C. burnetii replication rather than invasion.

\section{C. burnetii infection failed to induce a consistent inflammatory response in bovine epithelial cells}

We previously showed that $C$. burnetii induces a shortlasting but pronounced pro-inflammatory cytokine response in bovine macrophages in the early phase of infection [13]. Stimulation of udder epithelial cells with $E$. coli LPS resulted in a significant increase in mRNAs specific for IL- $1 \beta$, IL- 6 and TNF- $\alpha$, confirming the general ability of the cell line to respond to microbe-associated molecular patterns (Figure 8). Responses peaked at day 1 or day 2 and either declined upon prolonged stimulation (IL-1 $\beta$, TNF- $\alpha$ ) or remained elevated (IL-6). By stark contrast and despite the development of prominent CCVs in the udder epithelial cell line (see above), infection with

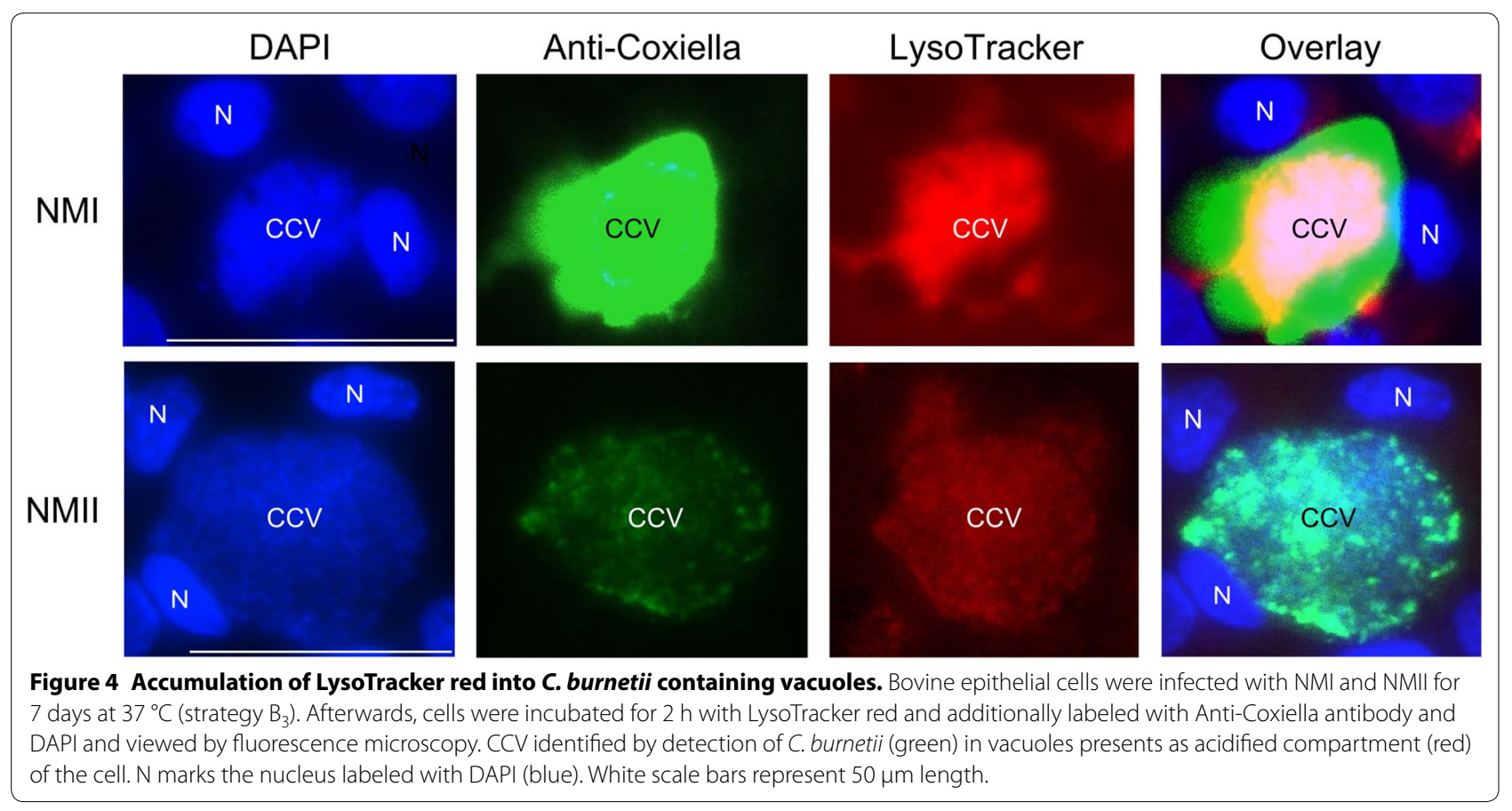



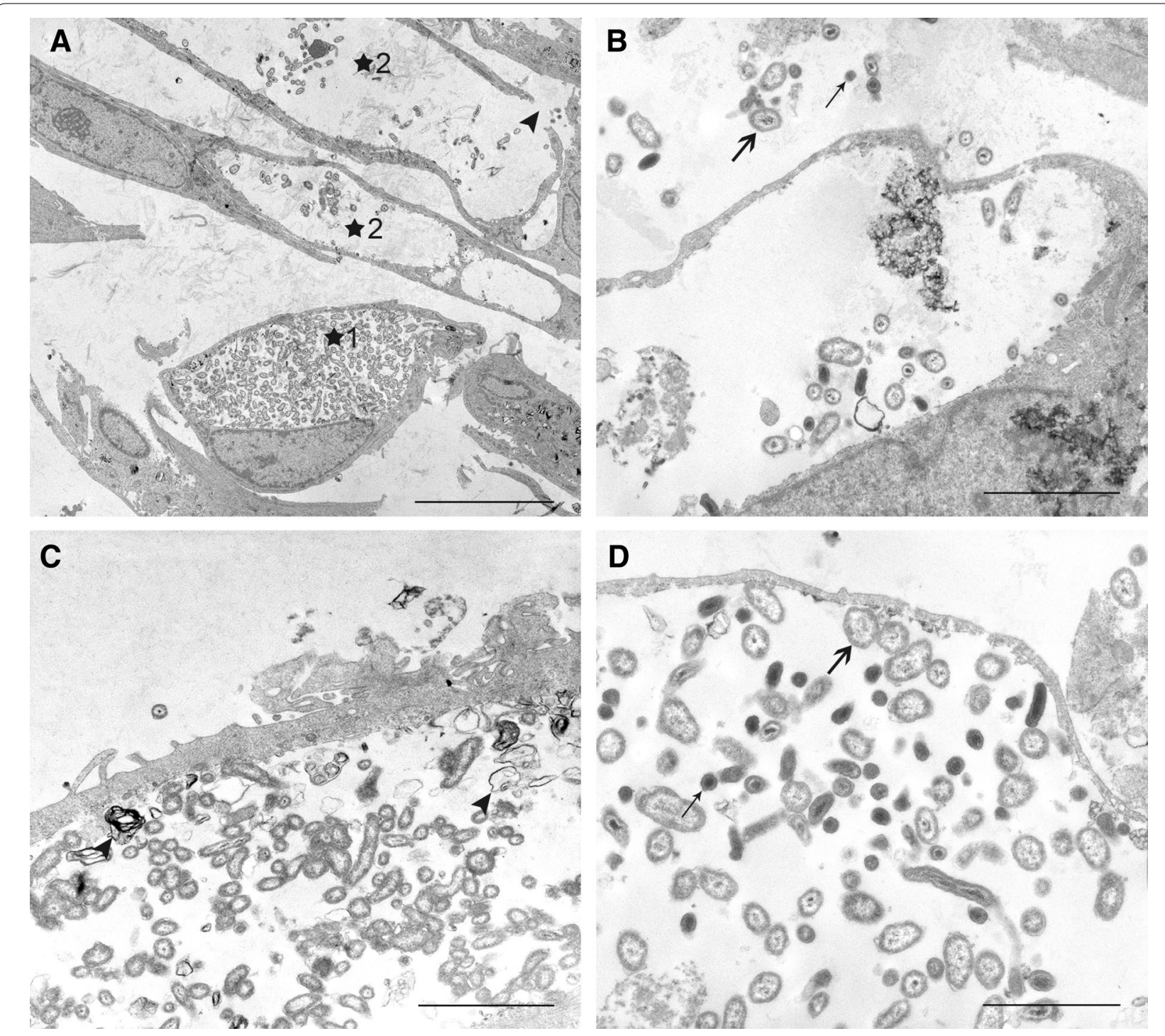

Figure 5 C. burnetii NMI and NMII in udder epithelial cells. A CCV in udder cells filled with numerous $\left({ }^{*} 1\right)$ or few $\left({ }^{*} 2\right)$ C. burnetii. Note ruptured CCV (arrowhead). 7 days pi NMII. Bar $=8.0 \mu \mathrm{m}$. B Extracellular LCV (thick arrow) and SCV (thin arrow) adjacent to a large CCV. 7 days pi. NMI. $\mathrm{Bar}=2.3 \mu \mathrm{m}$. C CCV containing predominantly LCV and small amounts of cellular debris (arrowheads). 7 days pi. NMII. Bar $=2.3 \mu \mathrm{m}$. D CCV filled with both LCV (thick arrow, exampl.) and SCV (thin arrow, exampl.). 7 days pi. NMII. Bar $=1.7 \mu \mathrm{m}$.

neither NMI nor NMII induced an up-regulation of the transcription of the respective cytokines after 1 day and after 7 days of infection. Lung, placental and gut epithelial cells responded to stimulation with E. coli LPS with gradual increases of cytokine mRNA expression over a time period of 7 days (data not shown) but also poorly responded to infection with NMI and NMII at 1 day pi (Figure 9). Only gut epithelial cells specifically reacted to NMI infection with a significant upregulation of IL-1 $\beta$, lung epithelial cells with a specific downregulation of IL-6 whereas infection with NMII resulted in a distinct up-regulation of TNF- $\alpha$ in lung epithelial cells.

\section{Discussion}

The bovine epithelial cell lines utilized in this study were selected as surrogates of certain steps in the infection path $C$. burnetii follows inside a mammalian host. The lung represents the entry site for the pathogen to establish the infection with alveolar macrophages considered to play a key role [22]. Placenta, gut and udder are known replication sites immediately prior to transmission events [2]. Here we demonstrated that C. burnetii invaded and replicated in bovine epithelial cells from the different organs without destroying the cell integrity or inducing a substantial immune response. Although the $C$. burnetii 


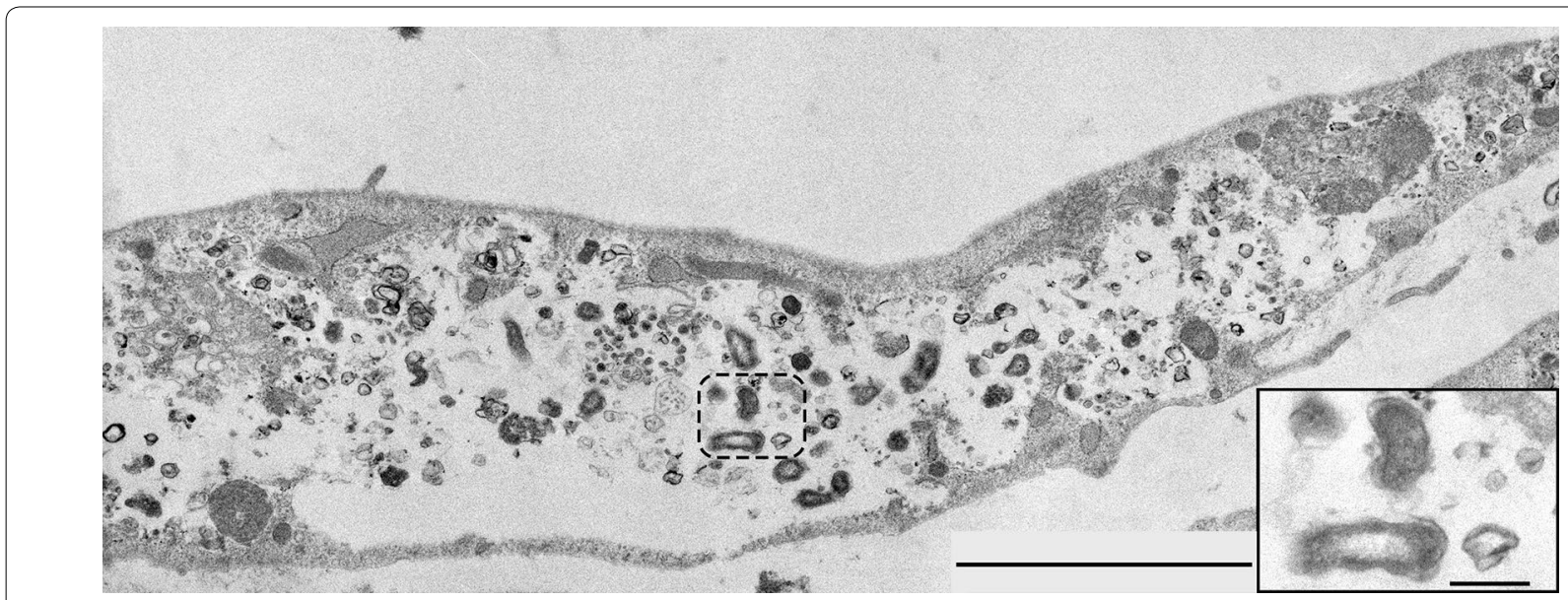

Figure 6 C. burnetii NMI in intestinal epithelial cells. A large phagolysosome replaces most of the cytoplasm. It contains large amounts of cellular debris and few C. burnetii (inside hatched line, example). The area indicated by the hatched line is shown as inset. It contains LCV with the characteristic gram-negative cell wall. 7 days pi. NM1. Bar $=3.0 \mu \mathrm{m}$, bar inset $=300 \mathrm{~nm}$.

strain NMI is considered more "virulent" than NMII as deduced from cell culture and rodent experiments, the invasiveness and replication efficacy in the bovine cell lines was similar. Epithelial cells from different organs differed in the individual kinetics of two steps in the cellular infection process. Udder epithelial cells were most effective in propagating C. burnetii mainly because of particularly supporting replication after bacterial invasion. Intestinal epithelial cells, by contrast, particularly supported bacterial invasion. The comparably higher replication efficacy detected for the latter cells when applying experimental strategy A as compared to strategy B points to ongoing invasion events even after $24 \mathrm{~h}$ of incubation which had paralleled bacterial replication. The interaction pattern with C. burnetii of these two cell types represented the extremes displayed by the cell lines under consideration with the suitability of lung, maternal and fetal epithelial cells to act as C. burnetii host cells ranging in-between.

Inoculation of bovine mammary gland epithelial cell cultures yielded the highest amounts of $C$. burnetii compared to cultures of epithelial cells from lung, gut and placenta after an incubation time of up to 7 days. Previous histological investigations of tissues from infected cattle primarily detected the pathogen in mammary gland epithelial cells (reviewed in [23]). Tropism for udder tissues in bovines seems to provide the basis for the high numbers of $C$. burnetii shed by milk in this species [9, 24, 25]. It is considered that consumption of dairy products poses a low risk for $\mathrm{Q}$ fever infections in humans [26] even though Benson et al. [27] had found that most bulk tank milk samples contained viable Coxiella organisms and human consumption of C. burnetii-containing milk leads to a rise in specific serum antibody titers in absence of clinical disease. A high bacterial load in raw milk was also described by Enright et al. [28], who observed up to 10000 infective doses of $C$. burnetii per $\mathrm{mL}$ of milk from infected dairy cows. Similar bacterial load was observed by Schaal [29] after quantitative analysis of Coxiella containing milk. High numbers of $C$. burnetii in milk at least contribute to spreading of the agent within cattle herds. Newborn calves fed C. burnetii-containing milk excrete the bacteria in their feces and urine into the environment [3]. Therefore a dairy herd showing no symptoms of Coxiellosis could still be a C. burnetii reservoir for transmission via the tick-independent infection cycle [24].

Typical C. burnetii containing structures (CCV) were observed in udder and intestinal epithelial cells by transmission electron microscopy. Mature CCV were seen at 7 days pi in udder cells. Findings are comparable to findings in Vero cells [30,31]. This indicates that both NMI and NMII undergo a complete replication cycle in these udder epithelial cells. The formation of large CCV requires protein secretion by $C$. burnetii [32] and depends on the actin cytoskeleton of the infected cells [33].

Small ruminants, like goats and sheep, shed C. burnetii more frequently via birth products [34] which contain huge numbers of bacteria and are the main source of environmental contamination and subsequent aerogenic transmission to humans. In ovine placentas, van Moll et al. [34] found Coxiella organisms in huge amounts in trophoblast cells which were embedded in acutely inflamed tissue. By contrast, bovine placentas generally contain few or moderate numbers of cells staining 


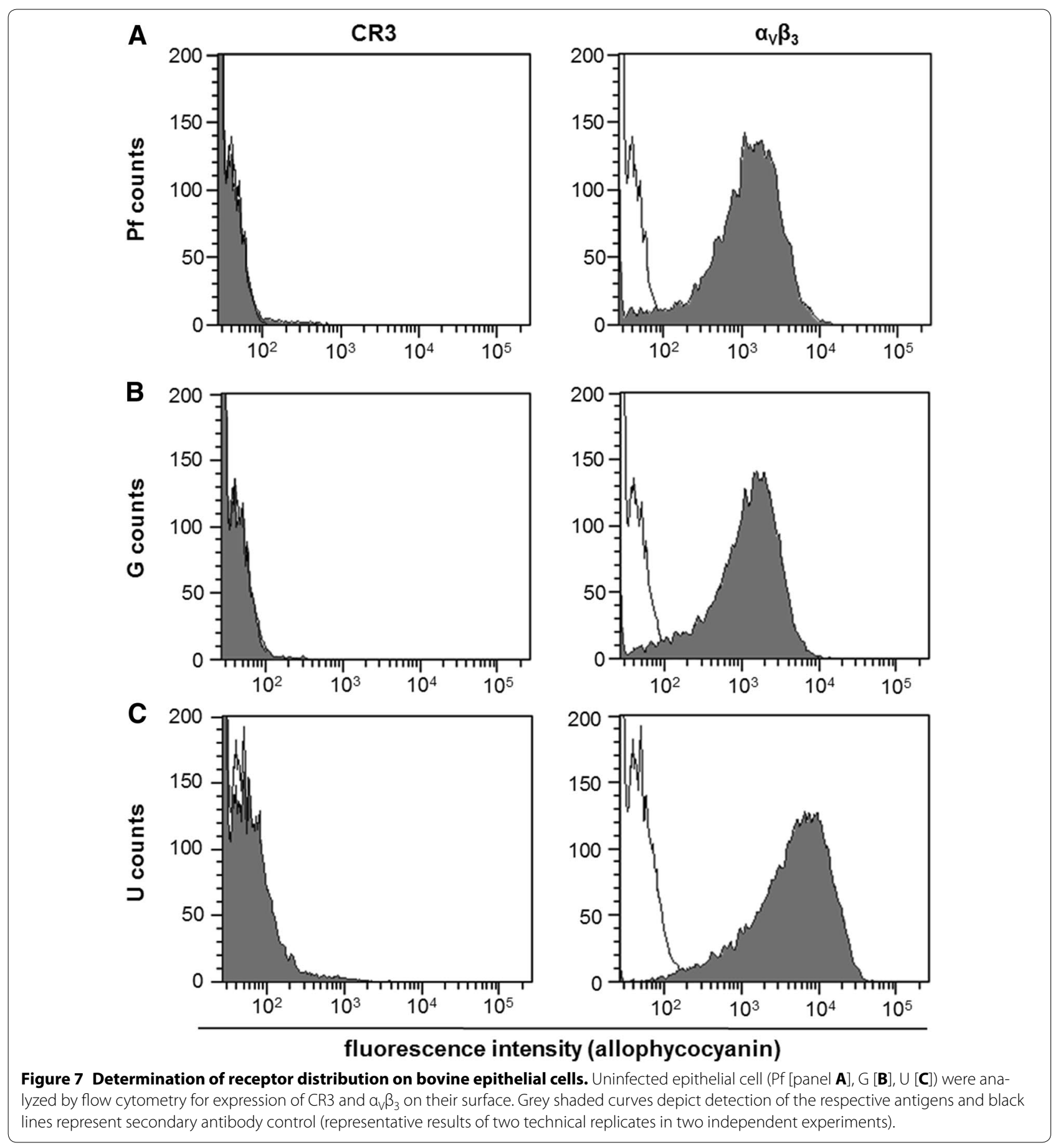

positive with Coxiella-specific antibodies and with rarely detectable Coxiella-like organisms. Our results of infection experiments with bovine fetal and maternal placental epithelial cell lines are in line with these ex vivo observations and imply that the many tissue-specific properties the placental cell lines have retained also comprise determinants of permissiveness for C. burnetii infection [35, 36].
Numbers of $C$. burnetii in the feces of infected small ruminants exceed numbers in bovine feces pointing to another possible shedding route at least in sheep and goats [9]. Feces of aborting ewes contain up to $10^{7} \mathrm{GE}$ of Coxiella per gram [37]. Our in vitro study showed that epithelial cells other than mammary gland epithelium also were capable of internalizing $C$. burnetii but there was little further propagation of bacterial numbers within 


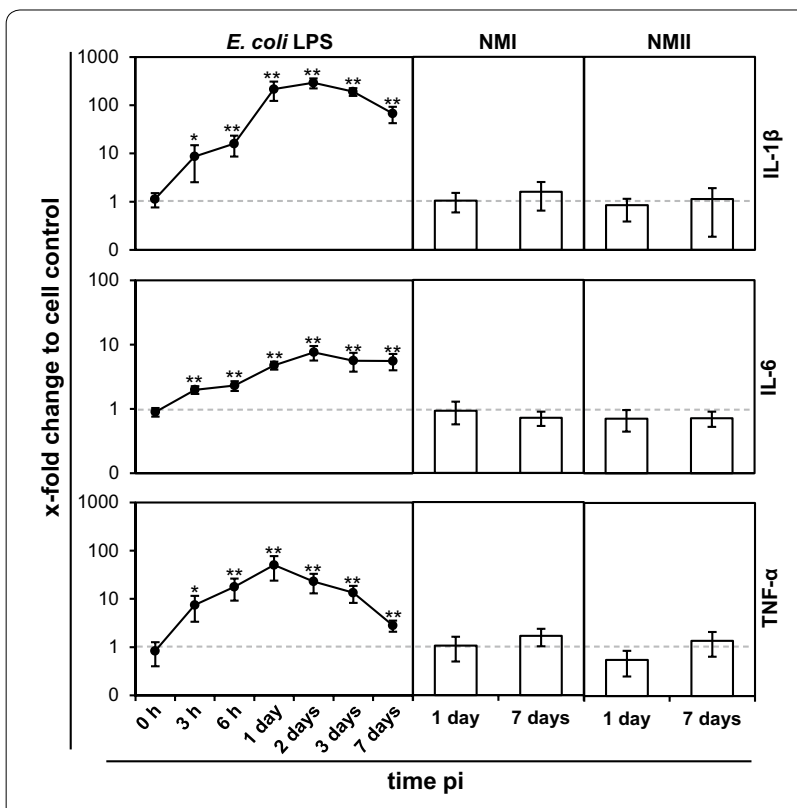

Figure 8 Cytokine expression of udder epithelial cells after stimulation with $E$. coli LPS or infection with C. burnetii. Amounts of mRNA specific for IL-1 $\beta$, IL- 6 and TNF- $\alpha$ after E. coli LPS stimulation $(5 \mu \mathrm{g} / \mathrm{mL})$ or infection with NMI and NMII were measured by qPCR at the time points after inoculation of cultures as indicated. The data were normalized based on the housekeeping gene GAPDH and the unstimulated or uninfected cell control. A randomisation test with a pair-wise reallocation was used to compare $\Delta C T$ (cycle threshold)-values from four independent experiments $\left({ }^{*} p \leq 0.05\right.$; $\left.{ }^{* *} p \leq 0.01\right)$

the cells. In organs implicated in C. burnetii shedding by cattle, these cells apparently represent rather unsuitable target cells which may be the in vitro correlate of the comparably low numbers of $C$. burnetii detected in the feces and birth fluids of bovines [9, 10].

At the entry site, lung epithelial cells are the first contact of Coxiella when entering the host organism after aerial transmission. It may be argued, that significant replication is not necessary at the entry site but the bacteria just cross the epithelial barrier to reach phagocytosing cells. Calverley et al. [38] concluded that recruited monocytes play an important role in the infection process because they control the distribution of bacteria from the lung. Additionally, resident alveolar immune cells were shown in a mouse model to possess a high susceptibility to Coxiella infection [38] and human and bovine alveolar macrophages can be infected with $C$. burnetii in vitro [13, 39]. There is cumulating evidence, therefore, that lung epithelial cells, being less susceptible to C. burnetii infection ([1], this study), do not act as replication sites for the bacteria and as such are poorly implicated in C. burnetii transmission between animals and in persistence in different hosts.
Bovine epithelial cells from different tissues varied in their susceptibility to $C$. burnetii invasion and support of replication with little correlation between the two properties as udder epithelial cells particularly supported $C$. burnetii replication whereas intestinal epithelial cells displayed an enhanced susceptibility for C. burnetii invasion. Invasion of $C$. burnetii into cells is reported to be influenced by the biochemical composition of the LPS [40]. In a variety of cells, C. burnetii strains with phase I and phase II LPS exhibit a different uptake kinetic in that a virulent phase I strain attached slower than the avirulent strain because of the mechanisms these organisms utilize to enter the host cells. Coxiella uses specific eukaryotic receptors such as integrins on macrophages and monocytes to adhere and invade [21]. C. burnetii phase I particles bind the leukocyte response integrin $\left(\alpha_{\mathrm{v}} \beta_{3}\right)$, whereas the avirulent $C$. burnetii additionally deploy complement receptor 3 (CR3) [21]. Bovine udder epithelial cells exhibited an enhanced $\alpha_{v} \beta_{3}$ expression whereas CR3 was essentially absent from the surface of all cell lines studied. Martinez et al. already described the first $C$. burnetii protein involved in host cell invasion [41]. OmpA is a surface protein of Coxiella that increased the internalization within non-phagocytic cells without necessity of Coxiella-specific receptors. Further investigations are required to assess the role of the adhesin OmpA and $\alpha_{v} \beta_{3}$ for bacterial attachment, invasion and cellular activation in bovine epithelial cells.

Coxiella organisms can activate immune cells in a straindependent manner. Especially avirulent strains promote a higher pro-inflammatory cytokine production compared to virulent strains [39] which may be linked to LPS phaserelated differences in attachment of the bacteria [42]. We observed a general failure to induce immune responses which particularly holds for udder epithelial cells independent of the phase-type of the NM variant and the day postinfection. Enterobacterial LPS is a very potent stimulant for immune reactions via pattern recognition receptors (PRRs) [43] and was included as positive control in our studies. LPS-stimulated udder epithelial cells showed an upregulation of pro-inflammatory cytokines. The failure of C. burnetii to initiate epithelial immune responses does not result from a process actively steered by a metabolically active pathogen, because infection studies with heat-inactivated NMI and NMII yielded similar results (data not shown). Invasive bacteria normally induce a rapid pro-inflammatory cytokine production as part of the defense mechanisms of the host. Different from bovine epithelial cells, attachment to or invasion of $C$. burnetii into macrophages stimulate a pro-inflammatory immune response to recruit additional immune cells $[13,39]$. However, these responses are regulated in a complex manner. Rasmussen et al. [44] described a delay in cytokine expression in Chlamydia spp.-infected 

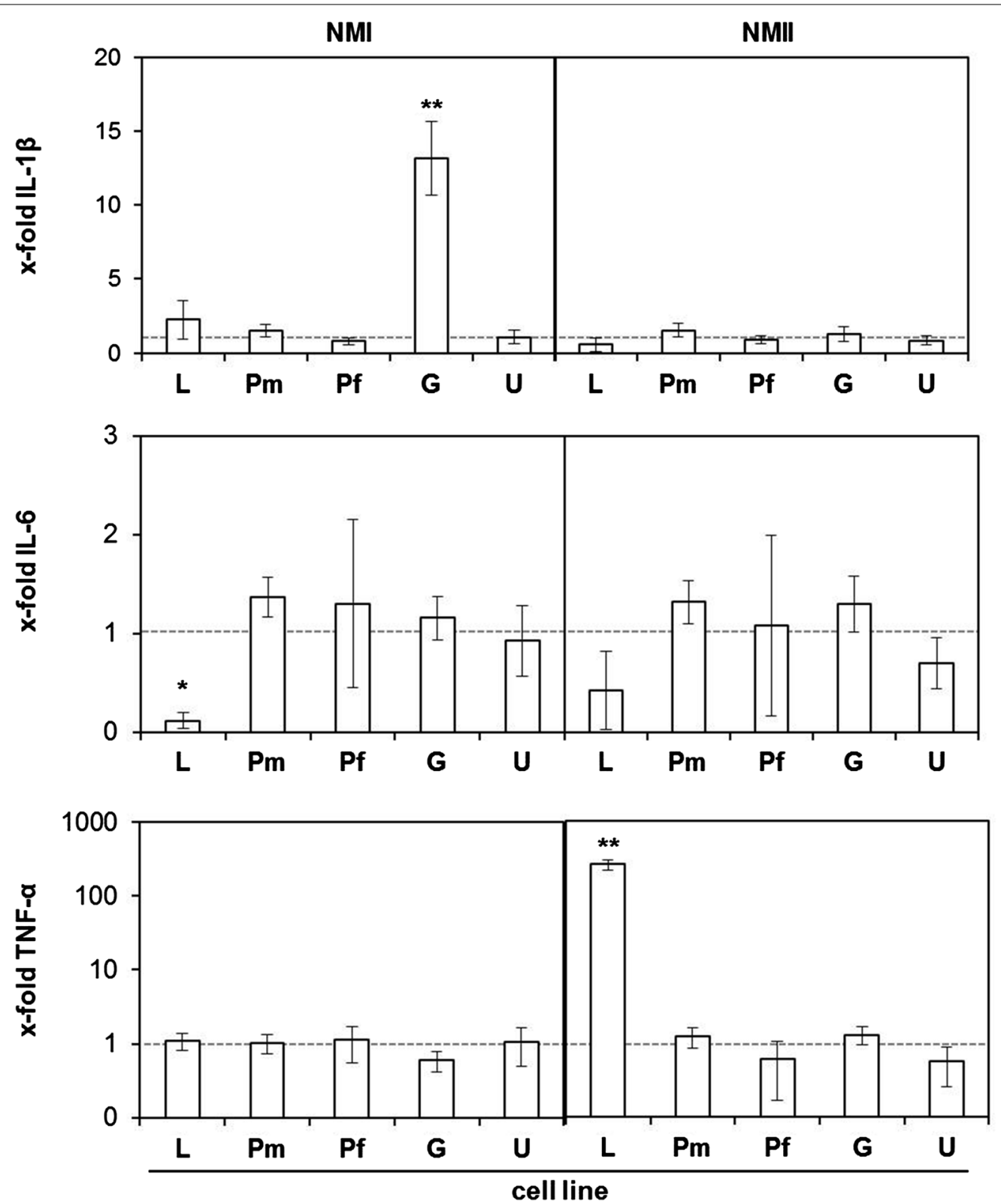

Figure 9 Cytokine expression of epithelial cells after infection with C. burnetii. Amounts of mRNA specific for IL-1 3 , IL-6 and TNF- $24 \mathrm{~h}$ after infection with NMI and NMII were measured by qPCR. The data were normalized based on the housekeeping gene GAPDH and the uninfected cell control. A randomisation test with a pair-wise reallocation was used to compare $\triangle C T$ (cycle threshold)-values from four independent experiments $\left({ }^{*} p \leq 0.05 ;{ }^{* *} p \leq 0.01\right)$.

cells and that chlamydial invasion alone did not induce an immune response. In human colon epithelial cells, activation of cytokine response upon bacterial invasion is dependent on a special set of signals [45]. The attachment alone did not sufficiently stimulate the immune system for bacterial clearance. Activation of epithelial cells by Candida albicans, a common epidermal pathogen, is regulated via two phases of signal pathway activation [46]. On the one hand there is a morphological recognition of the fungus via PRRs and on the other hand a second trigger leads to production of cytokines and further immune reactions inside the host cells. The molecular basis for failure of bovine epithelial cells investigated in our study to initiate inflammatory responses remains to be determined. It can be assumed, though, that this property of $C$. burnetii is instrumental to create a replicative niche in the reservoir host for persistence of the pathogen, similar to what Ben Amara et al. [47] had suggested for human trophoblasts. 
The in vitro cell system established and characterized in this study will be useful to further the understanding of the chain of events during the infection process of Coxiella organisms inside the bovine host in respect to epithelial cells as possible target cells. Bovine udder epithelial cells seem to have the highest permissiveness for C. burnetii and promote bacterial replication without losing the cell vitality. The udder cell line used was initially isolated from a mammary gland and became permanently cultivable by continuous passaging without deploying artificial transformation. The similarity to primary bovine mammary epithelial cells constitutes a big advantage for further investigations. Even though cell lines assessed in our study significantly varied in their permissiveness, the results strongly imply that $C$. burnetii can make use of epithelial cells beside immune cells as target cells for successful transmission between animals and into the environment as the cells survived the infection for substantial periods of time while helping the pathogen to evade the hosts immune response. For reasons of availability we chose bovine cells and evaluated the invasion and replication of C. burnetii by using two biological variants of a commonly used prototype strain. Cattle are not the main source of human infection but may shed $C$. burnetii. The high prevalence of $C$. burnetii genotype ST 20 recently identified in bovine milk in the U.S. [48] points to host species-specific adaptations within of the species of C. burnetii. After the proof-of-principle provided in this manuscript, studies are now in progress to assess quantitative differences in the interaction of different Coxiella genotypes with bovine epithelial cells.

\section{Competing interests}

The authors declare that they have no competing interests.

\section{Authors' contributions}

Design of study and experiments: CM, KS. Generation and characterization of cell lines: PG, PR, NH, CP. Cell infection assays, fluorescence microscopy and real-time PCR: KS, KB. Electron microscopy; ELT. Statistical analysis: KS. Interpretation of data and drafting of the manuscript: KS, KB, ELT, IDJ, CM. All authors read and approved the final manuscript.

\section{Acknowledgements}

The authors would like to thank Anja Müller, Anke Hinsching, Lisa Wirker und Wolfram Maginot (Friedrich-Loeffler-Institut, Institute of Molecular Pathogenesis) for their excellent technical assistance.

\section{Funding}

The study was financially supported by the European Commission (FP7 programme in the framework of the project "Antigone-ANTIcipating the Global Onset of Novel Epidemics", Project Number 278976). The funding body had no role in the design of the study and collection, analysis, and interpretation of data and in writing the manuscript.

\footnotetext{
Author details

${ }^{1}$ Institute of Molecular Pathogenesis, Friedrich-Loeffler-Institut (FLI), Naumburger Strasse 96a, 07743 Jena, Germany. ${ }^{2}$ ISP, INRA, Université Tours, UMR 1282, 37380 Nouzilly, France. ${ }^{3}$ Department of Anatomy, University of Veterinary Medicine Hannover, Bischofsholer Damm 15, 30173 Hannover, Germany ${ }^{4}$ Research Group Microbial Immunology, Leibniz Institute for Natural Product Research and Infection Biology/Hans Knoell Institute, Beutenbergstrasse 11a, 07745 Jena, Germany.
}

\section{Publisher's Note}

Springer Nature remains neutral with regard to jurisdictional claims in published maps and institutional affiliations.

Received: 11 October 2016 Accepted: 12 March 2017

Published online: 12 April 2017

\section{References}

1. Maurin M, Raoult D (1999) Q fever. Clin Microbiol Rev 12:518-553

2. Arricau-Bouvery N, Rodolakis A (2005) Is Q fever an emerging or reemerging zoonosis? Vet Res 36:327-349

3. Lang GH (1990) Coxiellosis (Q fever) in animals. In: Marrie TJ (ed) Q fever: the disease, vol 1. CRC Press, New York

4. Berri M, Souriau A, Crosby M, Crochet D, Lechopier P, Rodolakis A (2001) Relationships between the shedding of Coxiella burnetii, clinical signs and serological responses of 34 sheep. Vet Rec 148:502-505

5. Tissot-Dupont H, Amadei MA, Nezri M, Raoult D (2004) Wind in November, Q fever in December. Emerg Infect Dis 10:1264-1269

6. van der Hoek W, Morroy G, Renders NHM, Wever PC, Hermans MHA, Leenders ACAP, Schneeberger PM (2012) Epidemic Q fever in humans in the Netherlands. Adv Exp Med Biol 984:329-364

7. Sánchez J, Souriau A, Buendía AJ, Arricau-Bouvery N, Martínez CM, Salinas J, Rodolakis A, Navarro JA (2006) Experimental Coxiella burnetii infection in pregnant goats: a histopathological and immunohistochemical study. J Comp Pathol 135:108-115

8. Roest HJ, van Gelderen B, Dinkla A, Frangoulidis D, van Zijderveld F, Rebel $J$, van Keulen L (2012) Q fever in pregnant goats: pathogenesis and excretion of Coxiella burnetii. PLoS One 7:e48949

9. Rodolakis A, Berri M, Héchard C, Caudron C, Souriau A, Bodier CC, Blanchard B, Camuset P, Devillechaise P, Natorp JC, Vadet JP, Arricau-Bouvery $\mathrm{N}$ (2007) Comparison of Coxiella burnetii shedding in milk of dairy bovine, caprine, and ovine herds. J Dairy Sci 90:5352-5360

10. Guatteo R, Beaudeau F, Joly A, Seegers H (2007) Coxiella burnetii shedding by dairy cows. Vet Res 38:12

11. Valergakis GE, Russell C, Grogono-Thomas R, Bradley AJ, Eisler MC (2012) Coxiella burnetii in bulk tank milk of dairy cattle in south-west England. Vet Rec 171:156

12. Muskens J, van Engelen E, van Maanen C, Bartels C, Lam TJGM (2011) Prevalence of Coxiella burnetii infection in Dutch dairy herds based on testing bulk tank milk and individual samples by PCR and ELISA. Vet Rec 168:79

13. Sobotta K, Hillarius K, Mager M, Kerner K, Heydel C, Menge C (2016) Coxiella burnetii infects primary bovine macrophages and limits their host cell response. Infect Immun 84:1722-1734

14. Elliott A, Schoenlaub L, Freches D, Mitchell W, Zhang G (2015) Neutrophils play an important role in protective immunity against Coxiella burnetii infection. Infect Immun 83:3104-3113

15. Khavkin T, Tabibzadeh SS (1988) Histologic, immunofluorescence, and electron microscopic study of infectious process in mouse lung after intranasal challenge with Coxiella burnetii. Infect Immun 56:1792-1799

16. Toman R, Škultéty L (1996) Structural study on a lipopolysaccharide from Coxiella burnetii strain Nine Mile in avirulent phase II. Carbohydr Res 283:175-185

17. Roussel P, Cunha P, Porcherie A, Petzl W, Gilbert FB, Riollet C, Zerbe H, Rainard P, Germon P (2015) Investigating the contribution of IL-17A and IL-17F to the host response during Escherichia coli mastitis. Vet Res 46:56

18. Goellner S, Schubert E, Liebler-Tenorio E, Hotzel H, Saluz HP, Sachse K (2006) Transcriptional response patterns of Chlamydophila psittaci in different in vitro models of persistent infection. Infect Immun 74:4801-4808

19. Klee SR, Tyczka J, Ellerbrok H, Franz T, Linke S, Baljer G, Appel B (2006) Highly sensitive real-time PCR for specific detection and quantification of Coxiella burnetii. BMC Microbiol 6:2

20. Pfaffl MW, Horgan GW, Dempfle L (2002) Relative expression software tool (RESTC) for group-wise comparison and statistical analysis of relative expression results in real-time PCR. Nucleic Acids Res 30:e36

21. Capo C, Lindberg FP, Meconi S, Zaffran Y, Tardei G, Brown EJ, Raoult D, Mege JL (1999) Subversion of monocyte functions by Coxiella burnetii: 
impairment of the cross-talk between av $\beta 3$ integrin and CR3. J Immunol 163:6078-6085

22. Voth DE, Howe D, Heinzen RA (2007) Coxiella burnetii inhibits apoptosis in human THP-1 cells and monkey primary alveolar macrophages. Infect Immun 75:4263-4271

23. Agerholm JS (2013) Coxiella burnetii associated reproductive disorders in domestic animals - a critical review. Acta Vet Scand 55:13

24. Aitken DID, Bögel DK, Cracea PDE, Edlinger E, Houwers DD, Krauss PDH, Rády DM, Rehácek DJ, Schiefer PDHG, Kazán DJ, Schmeer DN, Tarasevich PDIV, Tringali PDG (1987) Q fever in Europe: current aspects of aetiology, epidemiology, human infection, diagnosis and therapy. Infection 15:323-327

25. Biberstein EL, Behymer DE, Bushnell R, Crenshaw G, Riemann HP, Franti CE (1974) A survey of Q fever (Coxiella burnetii) in California dairy cows. Am J Vet Res 35:1577-1582

26. Gale P, Kelly L, Mearns R, Duggan J, Snary EL (2015) Q fever through consumption of unpasteurised milk and milk products - a risk profile and exposure assessment. J Appl Microbiol 118:1083-1095

27. Benson WW, Brock DW, Mather J (1963) Serologic analysis of a penitentiary group using raw milk from a $\mathrm{Q}$ fever infected herd. Public Health Rep 78:707-710

28. Enright JB, Sadler WW, Thomas RC (1957) Pasteurization of milk containing the organism of $Q$ fever. Am J Public Health Nations Health 47:695-700

29. Schaal EH (1982) Udder colonization with Coxiella burnetii in cattle Q fever. Dtsch Tierarztl Wochenschr 89:411-414 (in German)

30. Coleman SA, Fischer ER, Howe D, Mead DJ, Heinzen RA (2004) Temporal analysis of Coxiella burnetii morphological differentiation. J Bacteriol 186:7344-7352

31. van Schaik EJ, Chen C, Mertens K, Weber MM, Samuel JE (2013) Molecular pathogenesis of the obligate intracellular bacterium Coxiella burnetii. Nat Rev Microbiol 11:561-573

32. Howe D, Melnicáková J, Barák I, Heinzen RA (2003) Maturation of the Coxiella burnetii parasitophorous vacuole requires bacterial protein synthesis but not replication. Cell Microbiol 5:469-480

33. Aguilera M, Salinas R, Rosales E, Carminati S, Colombo Ml, Berón W (2009) Actin dynamics and Rho GTPases regulate the size and formation of parasitophorous vacuoles containing Coxiella burnetii. Infect Immun 77:4609-4620

34. van Moll P, Baumgärtner W, Eskens U, Hänichen T (1993) Immunocytochemical demonstration of Coxiella burnetii antigen in the fetal placenta of naturally infected sheep and cattle. J Comp Pathol 109:295-301

35. Bridger PS, Menge C, Leiser R, Tinneberg HR, Pfarrer CD (2007) Bovine caruncular epithelial cell line (BCEC-1) isolated from the placenta forms a functional epithelial barrier in a polarised cell culture model. Placenta 28:1110-1117

36. Hambruch N, Haeger JD, Dilly M, Pfarrer C (2010) EGF stimulates proliferation in the bovine placental trophoblast cell line F3 via Ras and MAPK. Placenta 31:67-74

37. Joulié $A$, Laroucau K, Bailly $X$, Prigent $M$, Gasqui P, Lepetitcolin E, Blanchard B, Rousset E, Sidi-Boumedine K, Jourdain E (2015) Coxiella burnetii circulation in a naturally infected flock of dairy sheep: shedding dynamics, environmental contamination, and genotype diversity. Appl Environ Microbiol 81:7253-7260
38. Calverley M, Erickson S, Read AJ, Harmsen AG (2012) Resident alveolar macrophages are susceptible to and permissive of Coxiella burnetii infection. PLoS One 7:e51941

39. Graham JG, MacDonald LJ, Hussain SK, Sharma UM, Kurten RC, Voth DE (2013) Virulent Coxiella burnetii pathotypes productively infect primary human alveolar macrophages. Cell Microbiol 15:1012-1025

40. Baca OG, Klassen DA, Aragon AS (1993) Entry of Coxiella burnetii into host cells. Acta Virol 37:143-155

41. Martinez E, Cantet F, Fava L, Norville I, Bonazzi M (2014) Identification of OmpA, a Coxiella burnetii protein involved in host cell invasion, by multiphenotypic high-content screening. PLoS Pathog 10:e1004013

42. Dellacasagrande J, Ghigo E, Machergui-El S, Hammami Toman R, Raoult D, Capo C, Mege JL (2000) av $\beta 3$ integrin and bacterial lipopolysaccharide are involved in Coxiella burnetii-stimulated production of tumor necrosis factor by human monocytes. Infect Immun 68:5673-5678

43. Zamboni DS, Campos MA, Torrecilhas ACT, Kiss K, Samuel JE, Golenbock DT, Lauw FN, Roy CR, Almeida IC, Gazzinelli RT (2004) Stimulation of tolllike receptor 2 by Coxiella burnetii is required for macrophage production of pro-inflammatory cytokines and resistance to infection. J Biol Chem 279:54405-54415

44. Rasmussen SJ, Eckmann L, Quayle AJ, Shen L, Zhang YX, Anderson DJ, Fierer J, Stephens RS, Kagnoff MF (1997) Secretion of proinflammatory cytokines by epithelial cells in response to Chlamydia infection suggests a central role for epithelial cells in chlamydial pathogenesis. J Clin Investig 99:77-87

45. Jung HC, Eckmann L, Yang SK, Panja A, Fierer J, Morzycka-Wroblewska E, Kagnoff MF (1995) A distinct array of proinflammatory cytokines is expressed in human colon epithelial cells in response to bacterial invasion. J Clin Investig 95:55-65

46. Moyes DL, Richardson JP, Naglik JR (2015) Candida albicans-epithelial interactions and pathogenicity mechanisms: scratching the surface. Virulence 6:338-346

47. Ben Amara A, Ghigo E, Le Priol Y, Lépolard C, Salcedo SP, Lemichez E, Bretelle F, Capo C, Mege JL (2010) Coxiella burnetii, the agent of Q fever, replicates within trophoblasts and induces a unique transcriptional response. PLoS One 5:e15315

48. Pearson T, Hornstra HM, Hilsabeck R, Gates LT, Olivas SM, Birdsell DM, Hall CM, German S, Cook JM, Seymour ML, Priestley RA, Kondas AV, Clark Friedman CL, Price EP, Schupp JM, Liu CM, Price LB, Massung RF, Kersh GJ, Keim P (2014) High prevalence and two dominant host-specific genotypes of Coxiella burnetii in U.S. milk. BMC Microbiol 14:41

\section{Submit your next manuscript to BioMed Central and we will help you at every step:}

- We accept pre-submission inquiries

- Our selector tool helps you to find the most relevant journal

- We provide round the clock customer support

- Convenient online submission

- Thorough peer review

- Inclusion in PubMed and all major indexing services

- Maximum visibility for your research

Submit your manuscript at www.biomedcentral.com/submit
(O) BioMed Central 